\title{
Antioxidant activities of some edaphic algae in Egypt
}

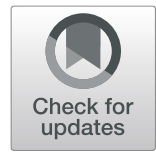

\author{
Neamat H. El-Tablawy*, Hoda A. Mansour and Abd El-Salam M. Shaaban
}

\begin{abstract}
Background: Algae in general characterized by their rich content of biological compounds. However, few studies were conducted on the soil-inhabiting algae and their antioxidant characteristics.

Results: The present study was designed to evaluate the antioxidant activity of four edaphic algae including one on-soil alga (Vaucheria geminata) and three axenic isolated in-soil algae (Pleurochloris pyrenoidosa, Botrydiopsis eriensis, and Scenedesmus obliquus). Total antioxidant activity by Phosphomolybdenum assay ranged from 6.66 to $36.33 \mathrm{mg}$ of Asc/g dwt; meanwhile, the percentage inhibition of DPPH radical was up to $97.37 \%$. Antioxidant activity of each alga was assessed also by measuring their contents of total phenols, flavonoids, and pigments (chlorophyll $a$ and carotenoids). B. eriensis and S. obliquus recorded the highest levels of phenols, flavonoids, and chlorophyll $a$ followed by P. pyrenoidosa and V. geminata, while B. eriensis showed the highest carotenoids content. Moreover, about seven types of each phenol and flavonoid compound were identified by HPLC chromatography in the four algae under investigation. The most common detected phenols were gallic, chlorogenic, caffeic, and ferulic, while rutin, quercetin, apigenin, and quercitrin were the most abundant flavonoids among all algae under investigation.

Conclusion: All the tested algae were characterized with high antioxidant activities besides the rich contents of compounds with antioxidant properties which recommend their further potential using in nutritional, pharmaceutical, and medicinal implications.
\end{abstract}

Keywords: Algae, Edaphic, Antioxidant, Phenols, Flavonoids, Chlorophyll, Carotenoids

\section{Background}

Algae are a diverse group of photosynthetic organisms representing the most abundant primary producers among all living organisms. They are usually inhabitants of aquatic biotopes either freshwater or marine, although they are widespread also in a wide range of ecological habitats including air, soil, or even extreme habitats [1]. Algae that occur in terrestrial habitats including either in or on soil surfaces are called edaphic algae. To cope with different environmental conditions, algae synthesize and accumulate a wide range of bioactive compounds [2-4].

\footnotetext{
* Correspondence: neamat.hassan@sci.asu.edu.eg

Department of Botany, Faculty of Science, Ain Shams University, Abbassia-11566, Cairo, Egypt
}

Microalgae have an interesting antioxidant system, which considered more effective due to the interactions among different compounds with antioxidant properties. The most powerful antioxidants found in algae being pigments, phenols, flavonoids, and vitamins [5]. The term antioxidant can be considered to describe any compound capable of quenching various forms of activated oxygen without itself undergoing conversion to a destructive form. In addition, when present at low concentrations significantly delays or prevents oxidation of different molecules by reactive oxygen species [6]. Accumulation of these destructive radicals can be extremely harmful to the cell components causing severe damage to crucial biomolecules such as nucleic acids, lipids, proteins, and carbohydrates [7].

\section{Springer Open}

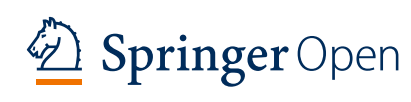

(c) The Author(s). 2020 Open Access This article is licensed under a Creative Commons Attribution 4.0 International License, which permits use, sharing, adaptation, distribution and reproduction in any medium or format, as long as you give appropriate credit to the original author(s) and the source, provide a link to the Creative Commons licence, and indicate if changes were made. The images or other third party material in this article are included in the article's Creative Commons licence, unless indicated otherwise in a credit line to the material. If material is not included in the article's Creative Commons licence and your intended use is not permitted by statutory regulation or exceeds the permitted use, you will need to obtain permission directly from the copyright holder. To view a copy of this licence, visit http://creativecommons.org/licenses/by/4.0/. 
Among antioxidants, phenolics comprise a wide range of compounds characterized with diverse physiological functions [8]. Various studies have reported the high phenolic content and antioxidant activity of many algal species [9-11]. In addition to its antioxidant characteristics, phenols documented in various researches for their antimicrobial, anti-inflammatory, and anti-proliferative activities on various types of cancer [12-14]. Also, the consumption of dietary supplements rich in polyphenols, associated with a lower risk of chronic diseases such as cardiovascular diseases [15]. Also, flavonoids, a group of phenolic compounds, found in many algae have a significant antioxidant activity. Many researches explored different types of flavonoids in many algae $[16,17]$. Flavonoids have a wide range of biological functions including anticarcinogenic, antimicrobial, anti-inflammatory, antidiabetic, and anti-obesity effects [18-21].

Moreover, algae have a wide range of pigments other than chlorophylls; most commonly carotenoids, phycobiliproteins, xanthophylls, etc. Pigments not only have an important role for algae in photosynthesis but also having antioxidative properties and other biological functions [22-24]. The advantage of using microalgae for pigment production is their high rate of growth as well as its ability to grow under adverse cultivation conditions. Different studies were conducted to increase the pigment yield from algae by manipulating their growth conditions such as light, temperature, and nutrients [25-27]. Chlorophyll from algae usually used in pharmaceutical applications as well as a natural additive in the food industry [28, 29]. Carotenoids also display very high antioxidant properties due to their ability for quenching reactive oxygen species [30]. Under specific growth conditions, some algae can increase their carotenoid content to high values [31, 32].

Finally, certain studies reported the antioxidant activities of algae especially seaweeds; however, few studies concerned with the antioxidant properties of microalgae especially algae growing on and in soil. So, the objective of the present study is to investigate different compounds such as phenols, flavonoids, chlorophylls, and carotenoids as well as their antioxidant properties in some soil-inhabiting algae.

\section{Methods}

\subsection{Sample collection and preparation}

Unialgal masses of Vaucheria geminata (Vaucher) De Candolle were collected from the soil surface of the humid canal near agricultural field at El Sharqia government ( $30^{\circ} 35^{\prime \prime}-51^{\circ} 04^{\prime \prime} \mathrm{N} / 31^{\circ} 44^{\prime \prime}-67^{\circ} 27^{\prime \prime}$ E). Samples were transported immediately into the lab, and siphons were collected gently from the surface of algal mats, shade-dried, and preserved in a dry place until phytochemical analysis. On the other hand, three algal taxa were isolated from different soil samples at Mit Helfa, Qalyoub, El Obour, and El Khankah (30 $14^{\prime \prime}-98^{\circ}$ $92^{\prime \prime} \mathrm{N} / 31^{\circ} 23^{\prime \prime}-52^{\circ} 29^{\prime \prime}$ E, $30^{\circ} 24^{\prime \prime}-92^{\circ} 69^{\prime \prime} \mathrm{N} / 31^{\circ}$ $48^{\prime}-02^{\circ} 98^{\prime \prime} \mathrm{E}$, and $30^{\circ} 23^{\prime \prime}-35^{\circ} 23^{\prime \prime} \mathrm{N} / 31^{\circ} 37^{\prime \prime}-96^{\circ}$ $77^{\prime \prime}$ E, respectively). Soil samples were enriched synthetic nutritive media (Chu\#10) for algal propagation, then algal samples were isolated and purified from any other microorganisms. The axenic algal samples include two yellow green algae (Pleurochloris pyrenoidosa Pasch and Botrydiopsis eriensis Snow) and one green alga (Scenedesmus obliquus Turpin Kütz). Identification of the four algal taxa was carried out [33, 34], while isolation of uni-algal samples was carried out using the plating and serial dilution method [35]. Under aseptic conditions, each isolate was cultivated in a sterilized BG 11 media for further mass culture according to the modified method [36]. Then, all flasks were kept in an incubator (with continuous light) at about $24{ }^{\circ} \mathrm{C}$ with continuous shaking until harvesting. After about 2 weeks, algal cultures were collected at the stationary phase and finally preserved dry at room temperature until phytochemical analysis also. Photomicrographs were taken using the binocular BEL photonics biological microscope fitted with a Canon Powershot G12 digital camera (Fig. 1a-d).

\subsection{Phycochemical analysis}

\subsubsection{Determination of total antioxidant capacity (TAC)}

Total antioxidant activities of crude methanolic extracts were determined [37]. Briefly, $0.3 \mathrm{ml}$ of sample solution $(0.1 \mathrm{mg} / \mathrm{ml})$ was mixed with $3.0 \mathrm{ml}$ reagent solution $(0.6$ $M$ sulfuric acid, $28 \mathrm{mM}$ sodium phosphate, and $4 \mathrm{mM}$ ammonium molybdate). Reaction mixture was incubated at $95{ }^{\circ} \mathrm{C}$ for $90 \mathrm{~min}$ in a water bath. The absorbance of all the sample mixture was measured at $695 \mathrm{~nm}$ with Unico 1201 spectrophotometer. Total antioxidant capacity is expressed as the number of equivalence of ascorbic acid.

\subsubsection{Assay of 1,1-diphenyl-2-picrylhydrazyl radical (DPPH)}

The DPPH radical scavenging assay was performed according to the method described by [38]. Mix the $0.5 \mathrm{ml}$ of algal methanolic extract with $0.5 \mathrm{ml}$ of $0.2 \mathrm{mM}$ DPPH solution (prepared with methanol) and incubate for 30 min in the dark at room temperature. The absorbance of each sample was recorded at $515 \mathrm{~nm}$ using Unico 1201 spectrophotometer. The percentage of scavenged DPPH radical was calculated according to the following equation:

$$
\begin{aligned}
& \text { DPPH scavenging activity }(\%) \\
& \quad=[1-(A s-A s c) / A c] \times 100
\end{aligned}
$$

where $A s$ is the absorbance of the sample (sample with $\mathrm{DPPH}), A s c$ is the absorbance of the sample control 

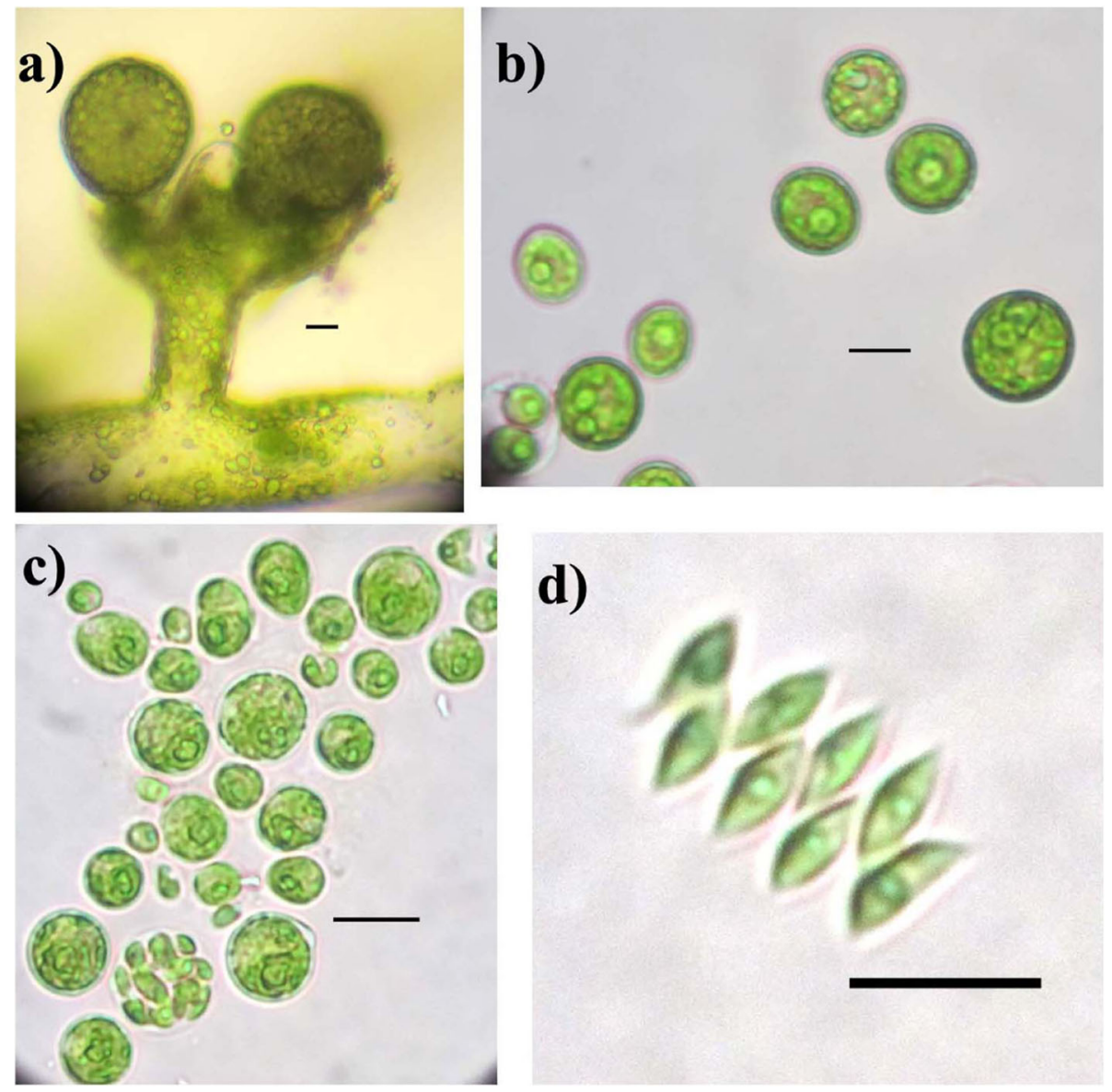

Fig. 1 Photomicrographs of algal samples (a) Vaucheria geminata, (b) Pleurochloris pyrenoidosa, (c) Botrydiopsis eriensis, and (d) Scenedesmus obliquus. Scale bar $=10 \mu$

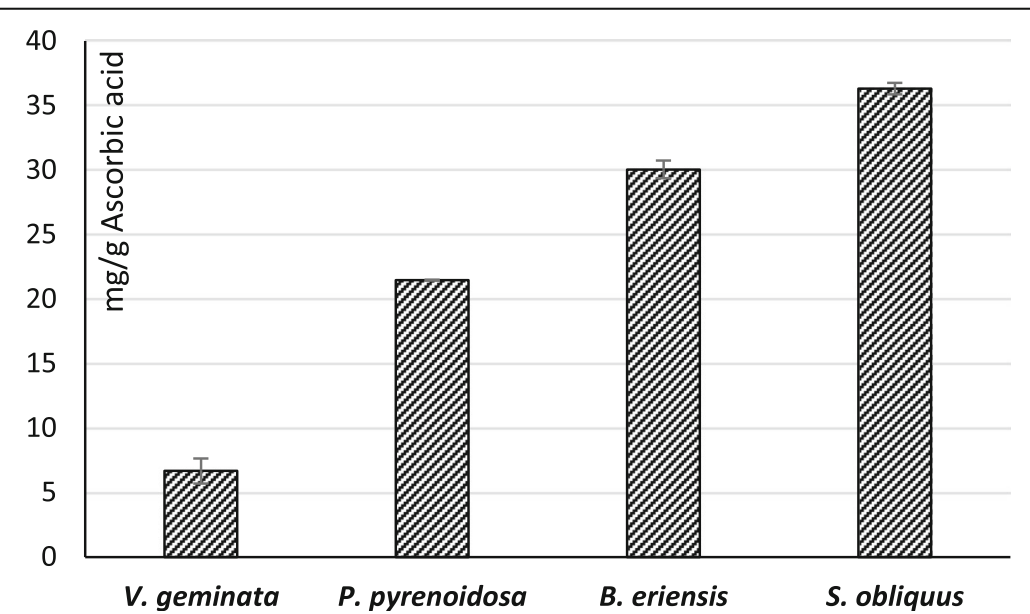

Fig. 2 Total antioxidant activity (Phosphomolybdenum assay) of methanol extract of $V$. geminata, P. pyrenoidosa, B. eriensis, and S. obliquus expressed as mg/g of ascorbic acid 


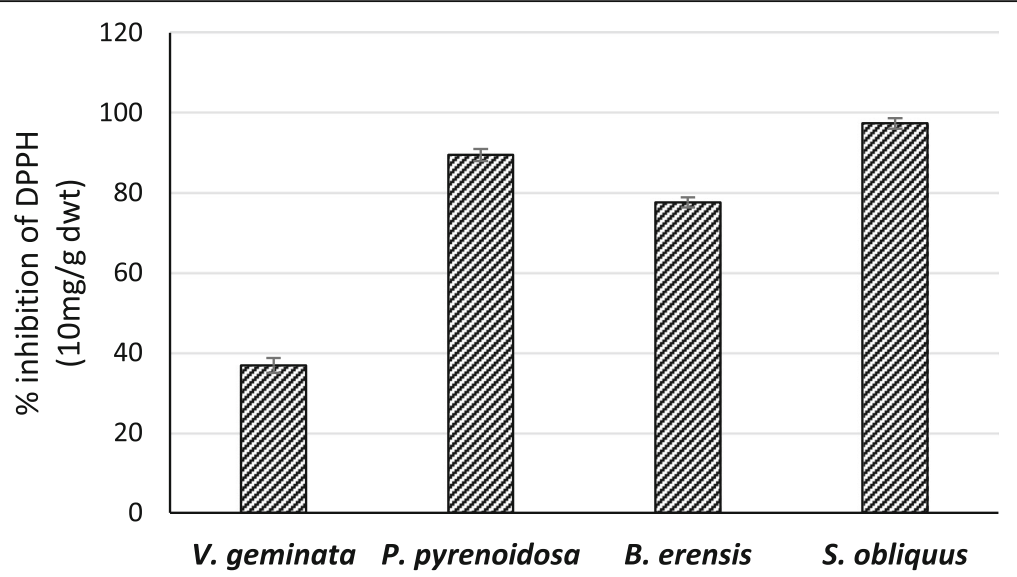

Fig. 3 Antioxidant activity (percentage inhibition of DPPH radical) of the methanol extract of $V$. geminata, P. pyrenoidosa, B. eriensis, and S. obliquus (10 mg/g dwt)

(sample in methanol), and $A c$ is the absorbance of the control (DPPH solution).

\subsubsection{Total phenols}

A known weight of algal samples was extracted with $80 \%$ cold methanol, and phenolic contents were determined by the method of [39]. Briefly, $0.1 \mathrm{ml}$ of each sample was mixed with $0.4 \mathrm{ml}$ of Folin-Ciocalteu reagent (10\%) and allowed to stand at room temperature for about $5 \mathrm{~min}$. Then, $0.5 \mathrm{ml}$ of $7.5 \% \mathrm{Na}_{2} \mathrm{CO}_{3}$ solution was added and the mixture incubated for $1.5 \mathrm{~h}$ in the dark at room temperature. Finally, the absorbance of each sample was measured at $760 \mathrm{~nm}$ with Unico 1201 spectrophotometer, and total phenols were calculated from a standard curve of gallic acid as milligram per gram dry weight.

\subsubsection{Total flavonoids}

The modified method was used for the determination of flavonoid contents [40]. About $0.5 \mathrm{ml}$ of methanolic extract was mixed with $1.5 \mathrm{ml}$ of $95 \%$ ethanol, $0.1 \mathrm{ml}$ of $10 \%$ aluminum chloride, $0.1 \mathrm{ml}$ of $1 \mathrm{M}$ potassium acetate, and $2.8 \mathrm{ml}$ of distilled water. After incubation at room temperature for $30 \mathrm{~min}$, the absorbance of the reaction mixture was measured at $415 \mathrm{~nm}$ with Unico
1201 spectrophotometer and Quercetin was used to make the calibration curve.

\subsubsection{Pigments}

Photosynthetic pigments (chlorophyll $a$ and carotenoids) were measured in the acetone algal extracts at wavelengths of 663 and $452.5 \mathrm{~nm}$ using Unico 1201 spectrophotometer [41]. Finally, the concentrations of the pigment fractions of chlorophyll $a$ and carotenoids were determined as microgram per milligram, according to the following equations:

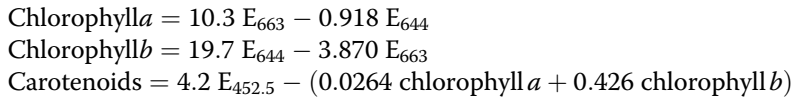

\subsubsection{Determination of phenols and flavonoids by HPLC}

Chromatographic separation of phenols and flavonoids of algal methanolic extracts was accomplished on a KROMASIL column $(150 \mathrm{~mm} \times 4.6 \mathrm{~mm})$ using HPLC device (GBC, Australia) with a UV/Vis detector and LC 1110 Pump at Al-Azhar university fungi research. The HPLC analysis was performed using methanol to water to tetrahydrofuran to acetic acid $(23: 75: 1: 1 \mathrm{v} / \mathrm{v} / \mathrm{v} / \mathrm{v})$ as a mobile phase with a flow rate of $1 \mathrm{ml} / \mathrm{min}$, and chromatograms were registered at UV $280 \mathrm{~nm}$ in case of

Table 1 Total phenols, total flavonoids content, and total antioxidant activity of V. geminata, P. pyrenoidosa, B. eriensis, and S. obliquus

\begin{tabular}{|c|c|c|c|c|}
\hline & V. geminata & P. pyrenoidosa & B. eriensis & S. obliquus \\
\hline Total phenols (mg/g dwt) & $13.68^{c} \pm 1.11$ & $27.07^{b} \pm 0.76$ & $30.89^{a} \pm 1.61$ & $29.25^{\mathrm{ab}} \pm 0.24$ \\
\hline Total flavonoids (mg/g dwt) & $9.59^{c} \pm 0.14$ & $16.84^{b} \pm 1.87$ & $24.73^{a} \pm 0.29$ & $22.34^{\mathrm{a}} \pm 0.32$ \\
\hline Total antioxidant activity (mg of ascorbic acid/g dwt) & $6.66^{d} \pm 0.96$ & $21.47^{c} \pm 0.04$ & $30.05^{b} \pm 0.69$ & $36.33^{\mathrm{a}} \pm 0.45$ \\
\hline Percentage inhibition of DPPH & $36.89^{d} \pm 3.83$ & $89.47^{b} \pm 1.53$ & $77.66^{\mathrm{C}} \pm 1.27$ & $97.37^{\mathrm{a}} \pm 1.33$ \\
\hline
\end{tabular}

Results are means \pm SE of three replicates

Different letters mean statistically significant differences $(p<0.05)$ 


\section{QTotal Phenols $\mathrm{Q}$ Total Flavonoids}

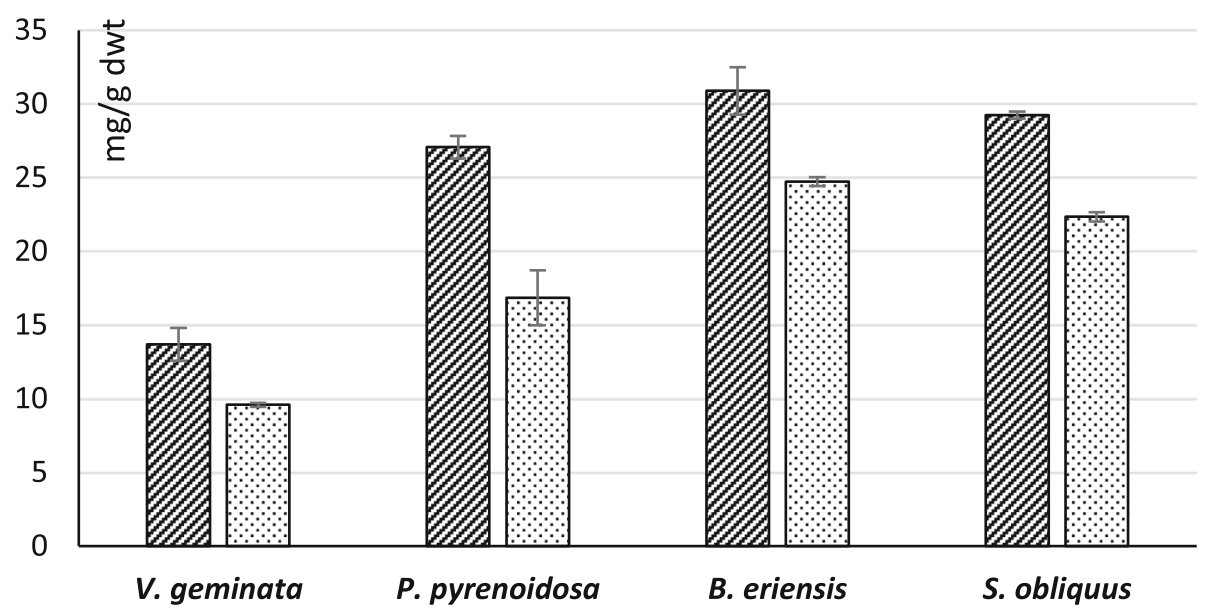

Fig. 4 Total phenols and total flavonoids of V. geminata, P. pyrenoidosa, B. eriensis, and S. obliquus as mg/g dwt

phenols. While for flavonoids, acetonitrile to water to formic acid $(85: 14: 1 \mathrm{v} / \mathrm{v} / \mathrm{v})$ was used as a mobile phase with a flow rate was $0.8 \mathrm{ml} / \mathrm{min}$, and chromatograms were registered at UV $356 \mathrm{~nm}$. Finally, qualitative and quantitative evaluation of both phenolic and flavonoid compounds were done by comparison of their retention times with those of pure standards using Win Chrome Chromatography Ver. 1.3 software.

\subsection{Statistical analysis}

Data are reported as mean \pm standard error from triplicate determination. The phytochemical analysis of samples was compared using one-way ANOVA (SPSS for Windows, version 20) to identify the significant difference $(p<0.05)$ between samples [42].

\section{Results}

\subsection{Total antioxidant activity}

The total antioxidant activity expressed by Phosphomolybdenum assay was illustrated in Fig. 2. Higher activity occupied by $S$. obliquus and $B$. eriensis followed by $P$. pyrenoidosa (36.33, 30.05, and 21.47 $\mathrm{mg}$ of ascorbic acid/g dwt, respectively) while lower activity was for $V$. geminata $(6.66 \mathrm{mg}$ of ascorbic acid/g dwt, respectively). Also, the percentage inhibition of DPPH radical was determined for all algal taxa under investigation. A maximum percentage of activity was for $S$. obliquus, $P$. pyrenoidosa, and $B$. eriensis (97.37, 89.47, and 77.66\%, respectively) and moderate activity for $V$. geminata $(36.89 \%)$ were detected (Fig. 3).

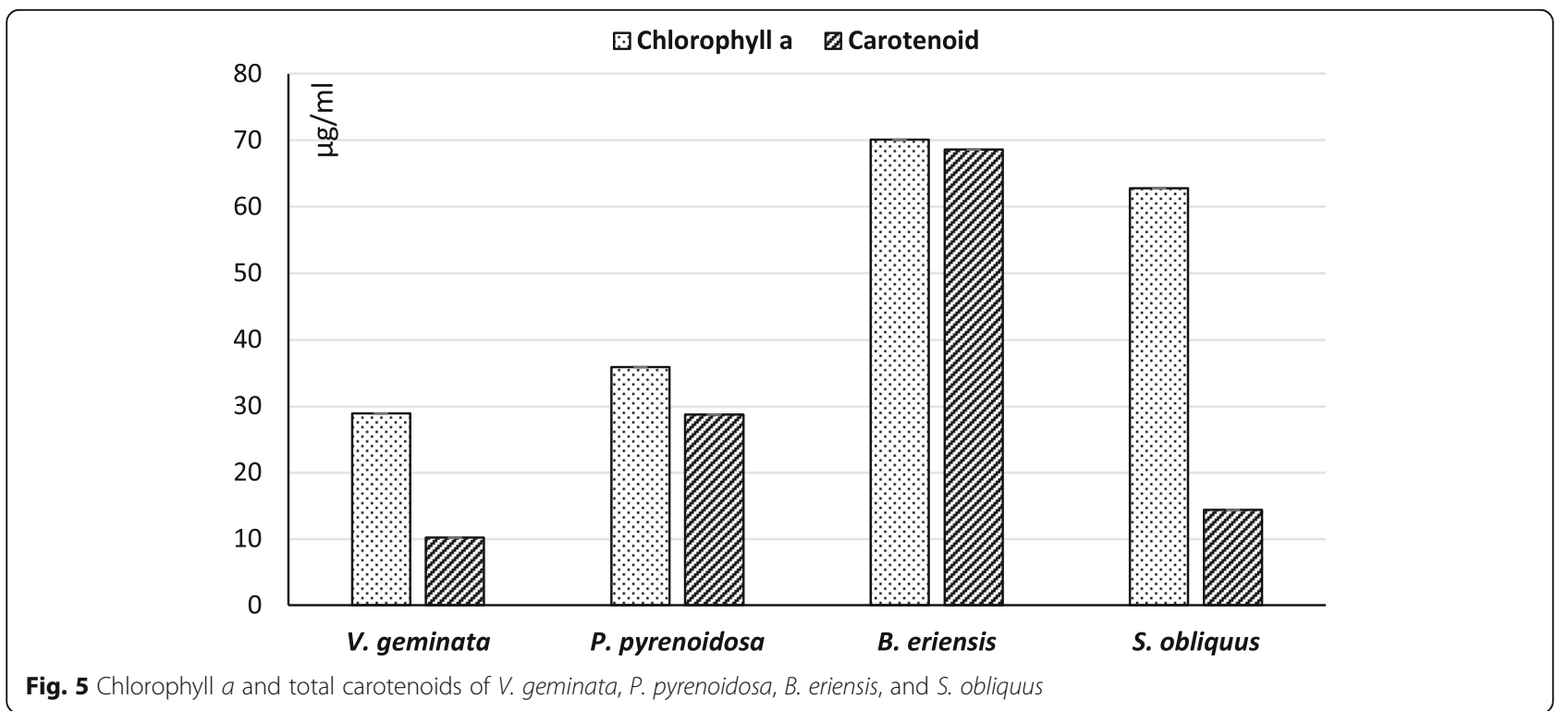


Table 2 Chlorophyll $a$ and carotenoid contents of V. geminata, P. pyrenoidosa, B. eriensis, and S. obliquus

\begin{tabular}{lllll}
\hline & V. geminata & P. pyrenoidosa & B. eriensis & S. obliquus \\
\hline Chlorophyll $a$ (mg/g dwt) & $0.29^{\mathrm{d}} \pm 0.003$ & $0.36^{c} \pm 0.005$ & $0.70^{\mathrm{a}} \pm 0.025$ & $0.63^{\mathrm{b}} \pm 0.003$ \\
Carotenoids (mg/g dwt) & $0.10^{\mathrm{d}} \pm 0.000$ & $0.29^{\mathrm{b}} \pm 0.006$ & $0.69^{\mathrm{a}} \pm 0.016$ & $0.14^{\mathrm{c}} \pm 0.003$
\end{tabular}

Results are mean \pm SE of three replicates

Different letters mean statistically significant differences $(p<0.05)$

\subsection{Total phenol and flavonoid content}

To determine the antioxidant activity of the algae under study, total phenols and total flavonoids were estimated (Table 1). Data revealed that both total phenol and flavonoid content showed a similar pattern in each alga. The maximum content of total phenols was detected in B. eriensis and S. obliquus (30.89 and $29.25 \mathrm{mg} / \mathrm{g} \mathrm{dwt}$, respectively) and for total flavonoids (22.05 and $22.34 \mathrm{mg} /$ g dwt, respectively), while $P$. pyrenoidosa showed moderate content of both phenol and flavonoid content (27.07 and $16.84 \mathrm{mg} / \mathrm{g} \mathrm{dwt}$, respectively). On the other hand, lower content of phenols and flavonoids (13.68 and 9.59 $\mathrm{mg} / \mathrm{g} \mathrm{dwt}$, respectively) were recorded in $V$. geminata (Fig. 4).

\subsection{Chlorophyll $a$ and carotenoid content}

Additionally, the pigment composition (chlorophyll $a$ and carotenoid) of the four algae was estimated (Fig. 5). It was noticeable that $B$. eriensis recorded the highest content of both chlorophyll $a$ and carotenoid (0.70 and $0.68 \mathrm{mg} / \mathrm{g} \mathrm{dwt}$, respectively). Although S. obliquus recorded higher content of chlorophyll $a$, lower carotenoid content was noticed $(0.63$ and $0.14 \mathrm{mg} / \mathrm{g}$ dwt, respectively). On the other hand, a moderate concentration of chlorophyll $a$ and carotenoid was detected in P. pyrenoidosa (0.36 and $0.29 \mathrm{mg} / \mathrm{g} \mathrm{dwt}$, respectively). In $V$. geminata, a lower value of both chlorophyll $a$ and carotenoids $(0.29$ and $0.10 \mathrm{mg} / \mathrm{g} \mathrm{dwt}$, respectively) was recorded (Table 2).

\subsection{Phenol and flavonoid identification by HPLC}

Moreover, phenol and flavonoid fractions were identified by HPLC (Tables 3 and 4). Seven different types of phenolic compounds were identified in $V$. geminata and $P$. pyrenoidosa while only five in B. eriensis and six in $S$. obliquus. From Fig. 6a, V. geminata revealed nearable data from 2.11 (syringic) to 4.52 (coumaric) $\mu \mathrm{g} / \mathrm{g}$ fwt. On the other hand, resorcinol and coumaric recorded maximum values $(4.73$ and $4.45 \mu \mathrm{g} / \mathrm{g}$ fwt) in P. pyrenoidosa (Fig. 6b). With regard to B. eriensis (Fig. 6c), a maximum value of caffeic followed by resorcinol, gallic and ferulic, and low ratio of chlorogenic (4.22, 3.95, 3.62, 3.11 , and $1.90 \mu \mathrm{g} / \mathrm{g}$ fwt, respectively). A maximum value for the green alga S. obliquus (Fig. 6d) was recorded for gallic and caffeic (3.44 and $3.42 \mu \mathrm{g} / \mathrm{g}$ fwt, respectively). Similarly, flavonoids exhibited a narrow range among all algae under investigation from 1.45 to $4.52 \mu \mathrm{g} / \mathrm{g}$ fwt. Seven types of flavonoids were detected in both $V$. geminata and P. pyrenoidosa while only five flavonoids for each B. eriensis and S. obliquus were recorded (Table 4). A maximum flavonoid value in $V$. geminata was for quercetin, and lowest value for hesperetin (3.34 and $1.45 \mu \mathrm{g} / \mathrm{g}$ fwt) as well as the nearable values of quercitrin, kaempferol, rutin, catechin, and apigenin (3.22, $3.15,2.70,2.13$, and $1.96 \mu \mathrm{g} / \mathrm{g}$ fwt, respectively) were detected (Fig. 7a). In P. pyrenoidosa (Fig. 7b), quercitrin and rutin reached its maximum value ( 4.52 and $4.13 \mu \mathrm{g}$ / $\mathrm{g}$ fwt, respectively). On the other side, B. eriensis (Fig. $7 \mathrm{c}$ ) recorded the highest content for quercitrin and apigenin ( 4.25 and $3.70 \mu \mathrm{g} / \mathrm{g}$ fwt, respectively). Finally, $S$. obliquus (Fig. $7 \mathrm{~d}$ ) showed a maximum value for quercetin, quercitrin and rutin, apigenin, and catechin (3.99, 3.97, and 3.54 $\mu \mathrm{g} / \mathrm{g}$ fwt, respectively).

\section{Discussion}

Several studies were conducted on the antioxidant activity of aquatic microalgae or seaweeds through the determination of their contents of phenols, flavonoids, or carotenoids [43-45]. In the current study, total phenols and flavonoids were estimated in order to evaluate the

Table 3 HPLC fractions of phenol content of $V$. geminata, P. pyrenoidosa, B. eriensis, and S. obliquus

\begin{tabular}{|c|c|c|c|c|c|c|}
\hline Phenols & Chemical structure & V. geminata & P. pyrenoidosa & B. eriensis & S. obliquus & Retention time \\
\hline Gallic & Benzoic derivative & 3.40 & 4.11 & 3.62 & 3.44 & 1.9 \\
\hline Resorcinol & Benzoic derivative & 3.66 & 4.73 & 3.95 & ND & 2.5 \\
\hline Chlorogenic & Cinnamic derivative & 2.91 & 3.42 & 1.90 & 3.09 & 3 \\
\hline Caffeic & Cinnamic derivative & 3.35 & 3.94 & 4.22 & 3.42 & 3.4 \\
\hline Coumaric & Cinnamic derivative & 4.52 & 4.45 & ND & 2.25 & 4.2 \\
\hline Ferulic & Cinnamic derivative & 4.02 & 3.30 & 3.11 & 3.21 & 5.1 \\
\hline Syringic & Benzoic derivative & 2.11 & 2.28 & ND & 1.33 & 8 \\
\hline
\end{tabular}


Table 4 HPLC fractions of flavonoid content of V. geminata, P. pyrenoidosa, B. eriensis, and S. obliquus

\begin{tabular}{lllllll}
\hline Flavonoids & Chemical structure & V. geminata & P. pyrenoidosa & B. eriensis & S. obliquus & Retention time \\
\hline Catechin & Proanthocyanidins & 2.13 & 2.32 & ND & 2.55 & 1.5 \\
Kaempferol & Flavonols & 3.15 & 3.77 & ND & ND & 2.9 \\
Rutin & Flavonols & 2.70 & 4.13 & 2.92 & 3.54 & 3.7 \\
Quercitrin & Flavonols & 3.22 & 4.52 & 2.25 & 3.97 & ND \\
Hesperetin & Flavanones & 1.45 & 3.46 & 3.70 & 2.58 & 4.9 \\
Apigenin & Flavones & 1.96 & 3.71 & 2.26 & 3.99 & 6.5 \\
Quercetin & Flavonols & 3.34 & 3.50 & & &
\end{tabular}

antioxidant capacity of four soil-inhabiting algae. From results, methanol extracts of Botrydiopsis eriensis, Scenedesmus obliquus, and Pleurochloris pyrenoidosa exhibited the highest contents of both total phenols and total flavonoids. Recent studies revealed similar total phenolic contents of Scenedesmus sp. to our work [46, 47]. Several studies have been concluded that phenolic compounds (along with flavonoids) of algae contribute significantly to their antioxidant capacity [48-50]. In addition to their antioxidant activity, these compounds display a wide range of biological activities which explains their commercial potential uses in nutritional, medicinal, and pharmaceutical applications [51-53].

Moreover, the phosphomolybdenum assay was performed to evaluate the total antioxidant activity of the algal taxa under investigation. Results revealed higher activity occupied by the methanol extracts of $S$. obliquus and $B$. eriensis followed by $P$. pyrenoidosa and lower

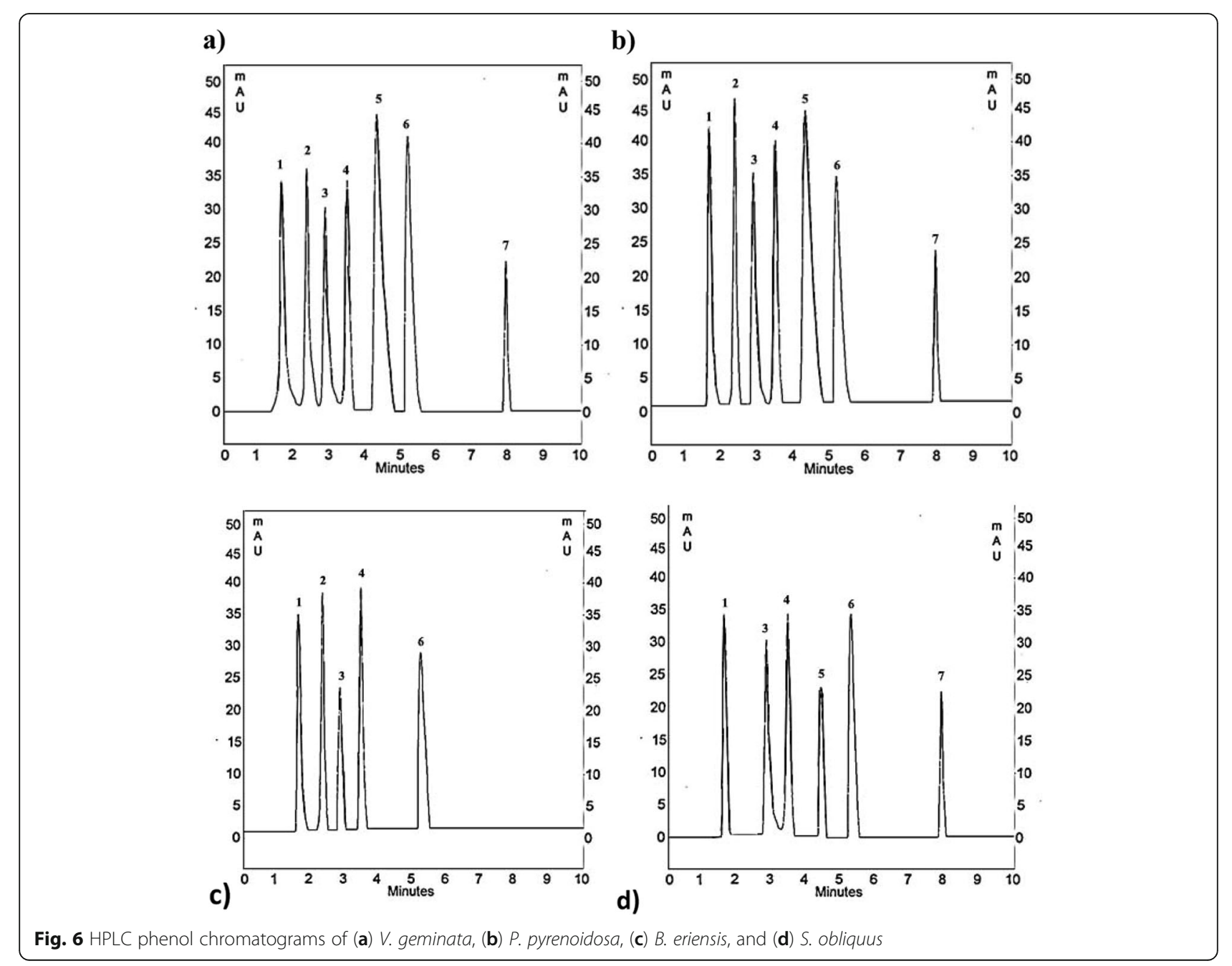


a)

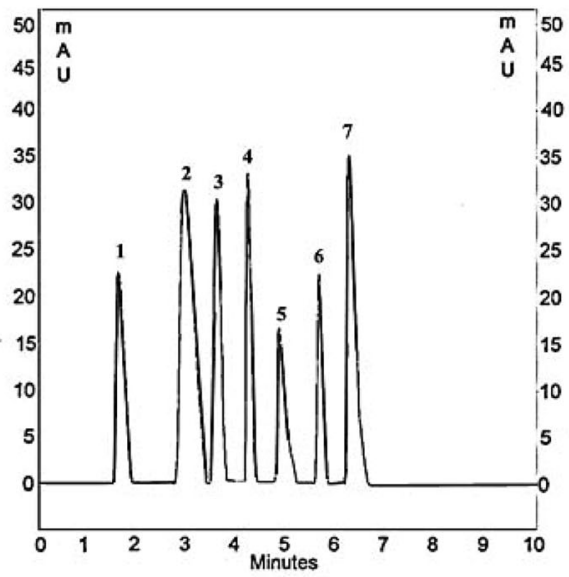

c)

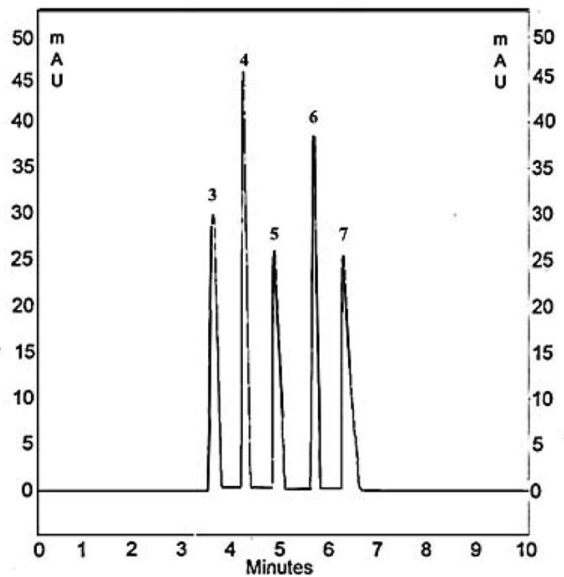

b)

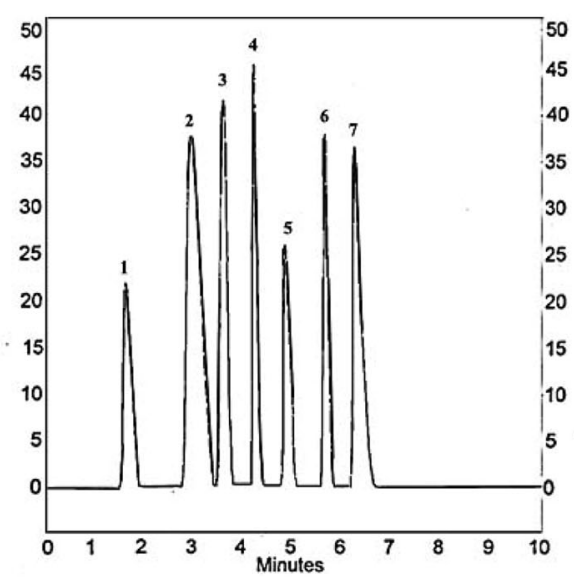

d)

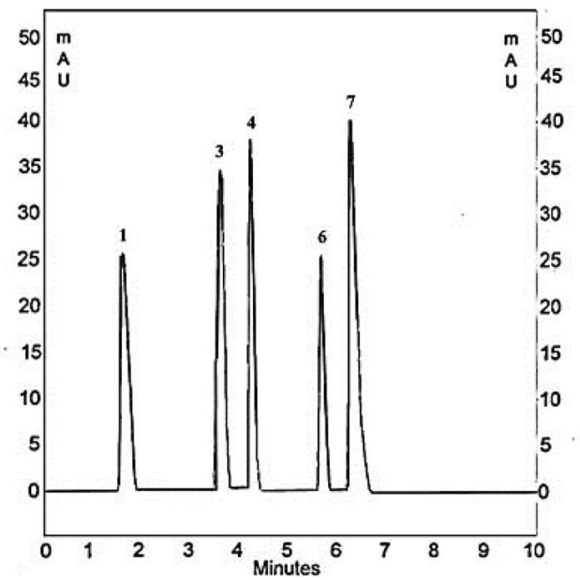

Fig. 7 HPLC flavonoid chromatograms of (a) V. geminata, (b) P. pyrenoidosa, (c) B. eriensis, and (d) S. obliquus

activity for Vaucheria geminata. In addition, the antioxidant activity expressed by measuring the percentage inhibition of DPPH radical recorded the very high antioxidant activity of most algae (up to $97 \%$ in S. obliquus). In agreement, other studies recorded the effective scavenging activity of DPPH radicals (up to 68.18\%) in some green algae in which also the highest content of total phenolic compounds was detected [54]. Particularly, Scenedesmus sp. reported by many authors contributing high antioxidant activity [55-57]. Recent studies explained the antioxidant potential of some green and yellow-green microalgae is comparable to the antioxidant activity displayed by raspberry fruit [58]. High antioxidant activity was observed in some algal members of Xanthophyta [59]. In exception, the lower antioxidant capacity of Vaucheria sessilis was observed in comparative studies of different algae [60]. On the other hand, relatively little known about the antioxidant capacity of Xanthophyta especially the currently isolated algae Botrydiopsis and Pleurochloris [61].
Although, it was reported before the high correlation between scavenging activity and total phenolic content of algae [10,43, 62]. In another studies, carotenoid and chlorophyll contents of algae contribute to their antioxidant potentiality $[44,63,64]$. So, the pigment composition represented by chlorophyll $a$ and carotenoid of the four studied algal taxa was estimated. Among all, $B$. eriensis reached the maximum contents of both chlorophyll $a$ and carotenoid followed by P. pyrenoidosa. However, a higher ratio of chlorophyll $a$ along with a lower carotenoid content was noticed in S. obliquus. The present finding agrees well with earlier reports on $S$. obliquus [65]. Chlorophyll and carotenoids are the major pigments in algae, and their concentrations can vary among algal species and according to the environmental conditions [66-68] as well as the extraction and purification techniques [69, 70]. Microalgae containing large quantities and different types of carotenoids with high nutritional values [71-73]. So, they represent natural alternatives for synthetic colorants exhibiting a strong 
antioxidant activity which have multiple applications in the food industry [74-76].

As the antioxidant activity of phenolic compounds depends largely on the chemical structure of these substances, the qualitative identification of phenols and flavonoids of the four studied algae was assessed also by HPLC chromatography. Seven types of phenolic compounds were identified nearly in all algae under study (gallic, resorcinol, chlorogenic, caffeic, coumaric, ferulic, and syringic). From results, the higher antioxidant capacity of $S$. obliquus in the present study may be due to their relative higher ratio of phenols of cinnamic nature (see Table 3). According to earlier studies [77], the capacity of quenching activity of phenols with cinnamic acid derivatives is more efficient than their benzoic counterparts exhibiting strong antioxidant activity [78-80]. Moreover, the biological functions of ferulic, caffeic, chlorogenic, and other phenolic cinnamic acids had been identified by various studies [81-83]. On the other hand, flavonoids are natural antioxidant phenolics found in many algae involved in various processes such as protection, signaling, and pigmentation [16]. The difference in flavonoids among the studied algae may be species-specific [84]. Results of flavonoids HPLC showed also that quercetin and quercitrin are the most abundant flavonoid compounds among all algae under investigation. Quercetin and its derivative rutin contents of some microalga are comparable to the levels in some highly flavonoid-containing vegetables and fruits $[16,17]$. In human health, algal flavonoids have many health-promoting benefits and protecting against different diseases [85]. In the current study, flavonoids of S. obliquus showed maximum value for quercetin followed by quercitrin, rutin, apigenin, and catechin. On the other hand, a maximum value for phenols was recorded for gallic followed by caffeic and chlorogenic. In agreement with our study, investigation of Scenedesmus sp. revealed similar results [46].

Finally, the higher antioxidant capacity of B. eriensis, P. pyrenoidosa, and S. obliquus in the present study could be explained by the rich amounts and synergic effects of phenolics, flavonoids, chlorophyll $a$, and/or carotenoids.

\section{Conclusion}

Previous studies were concerned with antioxidant activities of seaweeds, aquatic microalgae, and macroalgae. However, this study concerned with the edaphic algae including on and in-soil habitats. The investigated edaphic algae showed high antioxidant contents and activities, and so, they prospectively considered as promising natural antioxidant resources.
Abbreviations

DPPH: 2,2-Diphenyl-1-picrylhydrazyl; HPLC: High-performance liquid chromatography

\section{Acknowledgements}

Not applicable

\begin{abstract}
Authors' contributions
AMS designed the experimental approach, analyzed the data, and help in writing the manuscript. NHE carried out isolation of algae and all the phytochemical studies. NHE generated all the tables and figures in the manuscript. HAM helped to draft the manuscript. The authors read and approved the final manuscript.
\end{abstract}

\section{Funding}

Not applicable

Availability of data and materials

Not applicable

Ethics approval and consent to participate

Not applicable

Consent for publication

Not applicable

\section{Competing interests}

The authors declare that they have no competing interests.

Received: 20 January 2020 Accepted: 2 June 2020

Published online: 24 August 2020

References

1. Barsanti L, Gualtieri P (2014) Algae: anatomy, biochemistry, and biotechnology. CRC press

2. Xu L, Weathers PJ, Xiong X, Liu C (2009) Microalgal bioreactors: challenges and opportunities. Eng Life Sci 9:178-189

3. Harun R, Singh M, Forde GM, Danquah MK (2010) Bioprocess engineering of microalgae to produce a variety of consumer products. Renew Sustain Energy Rev 14:1037-1047

4. Chew KW, Yap JY, Show PL, Suan NH, Juan JC, Ling TC, Lee D-J, Chang J-S (2017) Microalgae biorefinery: high value products perspectives. Bioresour Technol 229:53-62

5. Rezayian M, Niknam V, Ebrahimzadeh H (2019) Oxidative damage and antioxidative system in algae. Toxicol Reports

6. Rose RC, Bode AM (1993) Biology of free radical scavengers: an evaluation of ascorbate. FASEB J 7:1135-1142

7. Halliwell B, Gutteridge JMC (1990) [1] Role of free radicals and catalytic metal ions in human disease: an overview. In: Methods in enzymology. Elsevier, pp 1-85

8. Dai J, Mumper RJ (2010) Plant phenolics: extraction, analysis and their antioxidant and anticancer properties. Molecules 15:7313-7352

9. Miranda MS, Sato S, Mancini-Filho J (2001) Antioxidant activity of the microalga Chlorella vulgaris cultered on special conditions. Boll Chim Farm 140:165-168

10. Jerez-Martel I, García-Poza S, Rodríguez-Martel G, Rico M, Afonso-Olivares C, Gómez-Pinchetti JL (2017) Phenolic profile and antioxidant activity of crude extracts from microalgae and cyanobacteria strains. J Food Qual 2017

11. Premkumar C, Divya M, Krishnaveni N, Santhanam P, Pachiappan P (2019) An Estimation of Antimicrobial and Antioxidant Activity of Microalgae. In: Basic and Applied Phytoplankton Biology. Springer, pp 303-314

12. Zhang H, Tsao R (2016) Dietary polyphenols, oxidative stress and antioxidant and anti-inflammatory effects. Curr Opin Food Sci 8:33-42

13. Mrabet A, García-Borrego A, Jiménez-Araujo A, Fernández-Bolaños J, Sindic M, Rodríguez-Gutiérrez G (2017) Phenolic extracts obtained from thermally treated secondary varieties of dates: Antimicrobial and antioxidant properties. LWT-Food Sci Technol 79:416-422

14. Ferhi S, Santaniello S, Zerizer S, Cruciani S, Fadda A, Sanna D, Dore A, Maioli M, D'hallewin G (2019) Total phenols from grape leaves counteract cell proliferation and modulate apoptosis-related gene expression in MCF-7 and HepG2 human cancer cell lines. Molecules 24:612 
15. Martin KR, Appel CL (2010) Polyphenols as dietary supplements: a doubleedged sword. Nutr Diet Suppl 2:12

16. Rico M, López A, Santana-Casiano JM, Gonzàlez AG, Gonzàlez-Dàvila M (2013) Variability of the phenolic profile in the diatom Phaeodactylum tricornutum growing under copper and iron stress. Limnol Oceanogr 58:144-152

17. Bulut O, Akın D, Sönmez C, Öktem A, Yücel M, Öktem HA (2019) Phenolic compounds, carotenoids, and antioxidant capacities of a thermo-tolerant Scenedesmus sp.(Chlorophyta) extracted with different solvents. J Appl Phycol 31:1675-1683

18. García-Lafuente A, Guillamón E, Villares A, Rostagno MA, Martínez JA (2009) Flavonoids as anti-inflammatory agents: implications in cancer and cardiovascular disease. Inflamm Res 58:537-552

19. Hossain K, Abdal Dayem A, Han J, Yin Y, Kim K, Kumar Saha S, Yang G-M, Choi H, Cho S-G (2016) Molecular mechanisms of the anti-obesity and antidiabetic properties of flavonoids. Int J Mol Sci 17:569

20. Alghazeer R, Elmansori A, Sidati M, Gammoudi F, Azwai S, Naas H, Garbaj A, Eldaghayes I (2017) In vitro antibacterial activity of flavonoid extracts of two selected libyan algae against multi-drug resistant bacteria isolated from food products. JBM 5:26-48

21. Yan X, Yang C, Lin G, Chen Y, Miao S, Liu B, Zhao C (2019) Antidiabetic potential of green seaweed Enteromorpha prolifera flavonoids regulating insulin signaling pathway and gut microbiota in type 2 diabetic mice. J Food Sci 84:165-173

22. Choubert G, Heinrich O (1993) Carotenoid pigments of the green alga Haematococcus pluvialis: assay on rainbow trout, Oncorhynchus mykiss, pigmentation in comparison with synthetic astaxanthin and canthaxanthin. Aquaculture 112:217-226 https://doi.org/https://doi.org/10.1016/00448486(93)90447-7

23. Christaki E, Bonos E, Florou-Paneri P (2015) Innovative microalgae pigments as functional ingredients in nutrition. In: Handbook of Marine Microalgae. Elsevier, pp 233-243

24. Pan-utai W, lamtham S (2019) Extraction, purification and antioxidant activity of phycobiliprotein from Arthrospira platensis. Process Biochem 82: 189-198

25. Ras M, Steyer J-P, Bernard O (2013) Temperature effect on microalgae: a crucial factor for outdoor production. Rev Environ Sci bio/technology 12: 153-164

26. Goiris K, Van Colen W, Wilches I, León-Tamariz F, De Cooman L, Muylaert K (2015) Impact of nutrient stress on antioxidant production in three species of microalgae. Algal Res 7:51-57

27. Thawechai T, Cheirsilp B, Louhasakul Y, Boonsawang P, Prasertsan P (2016) Mitigation of carbon dioxide by oleaginous microalgae for lipids and pigments production: Effect of light illumination and carbon dioxide feeding strategies. Bioresour Technol 219:139-149

28. Syarina PNA, Karthivashan G, Abas F, Arulselvan P, Fakurazi S (2015) Wound healing potential of Spirulina platensis extracts on human dermal fibroblast cells. EXCLI J 14:385

29. Sahni P, Aneja RK (2018) Development and characterization of natural food colorant from microalgae Chlorella sp.(Abca-17) and its use in food products. Indian J Ecol 45:194-200

30. Zuluaga M, Gueguen V, Pavon-Djavid G, Letourneur D (2017) Carotenoids from microalgae to block oxidative stress. Biolmpacts BI 7:1

31. Vidhyavathi R, Venkatachalam L, Sarada R, Ravishankar GA (2008) Regulation of carotenoid biosynthetic genes expression and carotenoid accumulation in the green alga Haematococcus pluvialis under nutrient stress conditions. J Exp Bot 59:1409-1418

32. Mulders KJM, Weesepoel $Y$, Bodenes $P$, Lamers PP, Vincken J-P, Martens DE, Gruppen H, Wijffels RH (2015) Nitrogen-depleted Chlorella zofingiensis produces astaxanthin, ketolutein and their fatty acid esters: a carotenoid metabolism study. J Appl Phycol 27:125-140

33. Dedusenko-Schegoleva NT, Hollerbach MM (1962) Field Guide of USSR Freshwater Algae. Xanthophyta

34. Prescott GW (1978) How to know the freshwater algae. Wm. C. C Brown Co Publ UK

35. Andersen RA (2005) Algal culturing techniques. Elsevier

36. Rippka R (1992) Pasteur culture collection of cyanobacterial strains in axenic culture. Cat Taxon handbook, Cat strains 1992/1993 1:1-103

37. Prieto P, Pineda M, Aguilar M (1999) Spectrophotometric quantitation of antioxidant capacity through the formation of a phosphomolybdenum complex: specific application to the determination of vitamin E. Anal Biochem 269:337-341
38. Cheng Z, Moore J, Yu L (2006) High-throughput relative DPPH radical scavenging capacity assay. J Agric Food Chem 54:7429-7436

39. Singleton VL, Rossi JA (1965) Colorimetry of total phenolics with phosphomolybdic-phosphotungstic acid reagents. Am J Enol Vitic 16:144158

40. Woisky RG, Salatino A (1998) Analysis of propolis: some parameters and procedures for chemical quality control. J Apic Res 37:99-105

41. Metzner H, Rau H, Senger H (1965) Untersuchungen zur Synchronisierbarkeit einzelner Pigmentmangel-Mutanten von Chlorella. Planta. https://doi.org/10.1007/BF00384998

42. Snedecor, George Waddel (2008). In: The Concise Encyclopedia of Statistics.

43. Li H-B, Cheng K-W, Wong C-C, Fan K-W, Chen F, Jiang Y (2007) Evaluation of antioxidant capacity and total phenolic content of different fractions of selected microalgae. Food Chem 102:771-776

44. Goiris K, Muylaert K, Fraeye I, Foubert I, De Brabanter J, De Cooman L (2012) Antioxidant potential of microalgae in relation to their phenolic and carotenoid content. J Appl Phycol 24:1477-1486

45. Fernando IPS, Kim M, Son K-T, Jeong Y, Jeon Y-J (2016a) Antioxidant activity of marine algal polyphenolic compounds: a mechanistic approach. J Med Food 19:615-628

46. Sahin SC (2019) Scenedesmus obliquus: A Potential Natural Source for Cosmetic Industry. Int J Second Metab 6:129-136

47. Patil L, Kaliwal BB (2019) Microalga Scenedesmus bajacalifornicus BBKLP-07, a new source of bioactive compounds with in vitro pharmacological applications. Bioprocess Biosyst Eng 42:979-994 https://doi.org/10.1007/ s00449-019-02099-5

48. Hajimahmoodi M, Faramarzi MA, Mohammadi N, Soltani N, Oveisi MR, Nafissi-Varcheh N (2010) Evaluation of antioxidant properties and total phenolic contents of some strains of microalgae. J Appl Phycol 22:43-50

49. Shetty V, Sibi G (2015) Relationship between total phenolics content and antioxidant activities of microalgae under autotrophic, heterotrophic and mixotrophic growth. J Food Resour Sci 4:1-9

50. Morowvat MH, Goharian S, Ghasemi Y (2019) Investigation of Antioxidant Properties of Three Naturally Isolated Microalgae: Identification and Bioinformatics Evaluation of the Most Efficient Strain. Recent Pat Biotechnol

51. Machu L, Misurcova L, Vavra Ambrozova J, Orsavova J, Mlcek J, Sochor J, Jurikova T (2015) Phenolic content and antioxidant capacity in algal food products. Molecules 20:1118-1133

52. Ali HI, Doumandji A (2017) Comparative phytochemical analysis and in vitro antimicrobial activities of the cyanobacterium Spirulina platensis and the green alga Chlorella pyrenoidosa: potential application of bioactive components as an alternative to infectious diseases. Bull l'Institut Sci Rabat, Sect Sci la Vie:41-49

53. Galasso C, Gentile A, Orefice I, lanora A, Bruno A, Noonan DM, Sansone C, Albini A, Brunet C (2019) Microalgal derivatives as potential nutraceutical and food supplements for human health: A focus on cancer prevention and interception. Nutrients 11:1226

54. Choochote W, Suklampoo L, Ochaikul D (2014) Evaluation of antioxidant capacities of green microalgae. J Appl Phycol 26:43-48 https://doi.org/10. 1007/s10811-013-0084-6

55. Guedes AC, Amaro HM, Pereira RD, Malcata FX (2011) Effects of temperature and $\mathrm{pH}$ on growth and antioxidant content of the microalga Scenedesmus obliquus. Biotechnol Prog 27:1218-1224

56. Stoica R, Velea S, llie L, Calugareanu M, Ghimis SB, Ion R-M (2013) The influence of ethanol concentration on the total phenolics and antioxidant activity of scenedesmus opoliensis algal biomass extracts. Rev Chim 64:304-306

57. Hamouda RA, El-Naggar NE-A, Abou-El-Seoud GW (2018) Enhancement of Pharmaceutical and Bioactive Components of Scenedesmus obliquus Grown Using Different Concentrations of KNO 3. Int J Pharmacol 14:758-765

58. Sansone C, Brunet C (2019) Promises and Challenges of Microalgal Antioxidant Production. Antioxidants 8:199

59. Assunção MFG, Amaral R, Martins CB, Ferreira JD, Ressurreição S, Santos SD, Varejão JMTB, Santos LMA (2017) Screening microalgae as potential sources of antioxidants. J Appl Phycol 29:865-877

60. Kartal M, Orhan I, Abu-Asaker M, Senol FS, Atici T, Sener B (2009) Antioxidant and anticholinesterase assets and liquid chromatography-mass spectrometry preface of various fresh-water and marine macroalgae. Pharmacogn Mag 5:291

61. Vuran V, Pabuccu K, Demiriz T, Elmastas M (2012) Antioxidant capacity and total phenolic compounds of Vaucheria geminata (Vaucher) DC. J Biotechnol 161:28 https://doi.org/https://doi.org/10.1016/j.jbiotec.2012.07. 075 
62. Siriwardhana N, Lee K-W, Jeon Y-J, Kim S-H, Haw J-W (2003) Antioxidant activity of Hizikia fusiformis on reactive oxygen species scavenging and lipid peroxidation inhibition. Food Sci Technol Int 9:339-346

63. Safafar H, Van Wagenen J, Møller P, Jacobsen C (2015) Carotenoids, phenolic compounds and tocopherols contribute to the antioxidative properties of some microalgae species grown on industrial wastewater. Mar Drugs 13:7339-7356

64. Sommella E, Conte G, Salviati E, Pepe G, Bertamino A, Ostacolo C, Sansone F, Prete F, Aquino R, Campiglia P (2018) Fast profiling of natural pigments in different spirulina (arthrospira platensis) dietary supplements by DI-FT-ICR and evaluation of their antioxidant potential by pre-column DPPH-UHPLC assay. Molecules 23:1152

65. Guedes AC, Gião MS, Matias AA, Nunes AVM, Pintado ME, Duarte CMM, Malcata FX (2013) Supercritical fluid extraction of carotenoids and chlorophylls a, b and c, from a wild strain of Scenedesmus obliquus for use in food processing. J Food Eng 116:478-482

66. Takaichi S (2011) Carotenoids in algae: distributions, biosyntheses and functions. Mar Drugs 9:1101-1118

67. White DA, Pagarette A, Rooks P, Ali ST (2013) The effect of sodium bicarbonate supplementation on growth and biochemical composition of marine microalgae cultures. J Appl Phycol 25:153-165

68. Ferreira da Silva V, Sant'Anna C (2017) Impact of culture conditions on the chlorophyll content of microalgae for biotechnological applications. World J Microbiol Biotechnol 33:20

69. Jaeschke DP, Rech R, Marczak LDF, Mercali GD (2017) Ultrasound as an alternative technology to extract carotenoids and lipids from Heterochlorella luteoviridis. Bioresour Technol 224:753-757

70. Saini RK, Keum Y-S (2018) Carotenoid extraction methods: A review of recent developments. Food Chem 240:90-103

71. Mortensen A (2006) Carotenoids and other pigments as natural colorants. Pure Appl Chem 78:1477-1491

72. Wrolstad RE, Culver CA (2012) Alternatives to those artificial FD\&C food colorants. Annu Rev Food Sci Technol 3:59-77

73. Wang F, Huang L, Gao B, Zhang C (2018) Optimum production conditions, purification, identification, and antioxidant activity of violaxanthin from microalga Eustigmatos cf. polyphem (Eustigmatophyceae). Mar Drugs 16:190

74. Fernando IPS, Nah J-W, Jeon Y-J (2016b) Potential anti-inflammatory natural products from marine algae. Environ Toxicol Pharmacol 48:22-30

75. Levine I, Fleurence J (2018) Microalgae in health and disease prevention. Academic Press

76. Barbalace MC, Malaguti M, Giusti L, Lucacchini A, Hrelia S, Angeloni C (2019) Anti-Inflammatory Activities of Marine Algae in Neurodegenerative Diseases. Int J Mol Sci 20:3061

77. Natella F, Nardini M, Di Felice M, Scaccini C (1999) Benzoic and cinnamic acid derivatives as antioxidants: Structure- activity relation. J Agric Food Chem 47:1453-1459

78. Sova M (2012) Antioxidant and antimicrobial activities of cinnamic acid derivatives. Mini Rev Med Chem 12:749-767

79. Hafizur RM, Hameed A, Shukrana M, Raza SA, Chishti S, Kabir N, Siddiqui RA (2015) Cinnamic acid exerts anti-diabetic activity by improving glucose tolerance in vivo and by stimulating insulin secretion in vitro. Phytomedicine 22:297-300

80. Lima TC, Ferreira AR, Silva DF, Lima EO, de Sousa DP (2018) Antifungal activity of cinnamic acid and benzoic acid esters against Candida albicans strains. Nat Prod Res 32:572-575

81. Akao Y, Maruyama H, Matsumoto K, Ohguchi K, Nishizawa K, Sakamoto T, Araki Y, Mishima S, Nozawa Y (2003) Cell growth inhibitory effect of cinnamic acid derivatives from propolis on human tumor cell lines. Biol Pharm Bull 26:1057-1059

82. Kumar N, Pruthi V (2014) Potential applications of ferulic acid from natural sources. Biotechnol Reports 4:86-93

83. Peperidou A, Pontiki E, Hadjipavlou-Litina D, Voulgari E, Avgoustakis K (2017) Multifunctional cinnamic acid derivatives. Molecules 22:1247

84. Goiris K, Muylaert K, Voorspoels S, Noten B, De Paepe D, GJ EB, De Cooman $L$ (2014) Detection of flavonoids in microalgae from different evolutionary lineages. J Phycol 50:483-492

85. Michalak I, Chojnacka K (2015) Algae as production systems of bioactive compounds. Eng Life Sci 15:160-176

\section{Publisher's Note}

Springer Nature remains neutral with regard to jurisdictional claims in published maps and institutional affiliations.

\section{Submit your manuscript to a SpringerOpen ${ }^{\circ}$ journal and benefit from:}

- Convenient online submission

- Rigorous peer review

- Open access: articles freely available online

- High visibility within the field

- Retaining the copyright to your article

Submit your next manuscript at $\boldsymbol{\nabla}$ springeropen.com 